J. Clin. Chem. Clin. Biochem.

Vol. 14, 1976, pp. 407-410

\title{
Turbidimetric Determination of Haptoglobin
}

\author{
By J. M. Ramakers and H.J. H. Kreutzer
}

From the laboratory Groot Ziekengasthuis, Nieuwstraat 34, 's-Hertogenbosch, Netherlands

(Received January 22/April 27, 1976)

Summary: A specific, acurate and simple determination of haptoglobin is described with an antiserum against the antigenic determinants of the three haptoglobin phenotypes 1-1, 2-1 and 2-2. Antihaptoglobin is the determining factor in the formation of an antigen-antibody complex with maximal light absorption properties. Haptoglobin concentration is expressed as hemoglobin binding capacity. For the three haptoglobin phenotypes we found similar correlation between the turbidimetric method and the direct measurement of hemoglobin binding capacity by agarelectrophoresis.

\section{Turbidimetrische Bestimmung von Haptoglobin}

Zusammenfassung: Eine einfache, spezifische und genaue Methode zur Haptoglobinbestimmung mit einem Antiserum gegen die Antigendeterminanten der drei Haptoglobintypen 1-1, 2-1 und 2-2 wird beschrieben. Antihaptoglobin ist der begrenzende Faktor bei der Bildung eines maximal lichtabsorbierenden Antigen-Antikörper-Komplexes. Die Haptoglobinkonzentration wird als Hämoglobin-Bindungskapazität angegeben. Wir fanden für die drei Haptoglobintypen eine gute Korrelation zwischen turbidimetrischer Methode und der direkten Bestimmung der Hämoglobin-Bindungskapazität durch Agarelektrophorese.

\section{Introduction}

A turbidimetric determination of haptoglobin (Hp) is possible by immuno-precipitation in liquid environment (1). In the precipitin reaction of a protein with its antiserum, the antigen-antibody complexes can form larger aggregates which are able to absorb incident light. In general, a premise for the composition of larger immunoaggregates is the presence of certain optimal concentrations of antigen and antibody. When an excess of antigen is present, it groups around the antibody, and thereby causes small aggregates, whilst an excess of antibody groups around the antigen, and thereby also prompts the formation of small aggregates.

The haptoglobin antigens partially display the same behaviour, as is shown in this paper.

The concentration of antigen which is determined turbidimetrically is expressed in $\mu$ mol hemoglobin binding capacity per liter. Reaction conditions are similar to that described earlier (2).

\section{Materials and Methods}

Tris buffer ( $0.2 \mathrm{~mol} / 1, \mathrm{pH} 7.5)$.

24.2 Tris-hydroxymethylaminomethane was dissolved in $800 \mathrm{ml}$ distilled water. The $\mathrm{pH}$ was adjusted to 7.5 with $\mathrm{HCl}$
$6 \mathrm{~mol} / \mathrm{l}$ and the volume adjusted to $1000 \mathrm{ml}$. The buffer was diluted 1:100 daily with distilled $\mathrm{CO}_{2}$-free water.

Rabbit anti-haptoglobin was obtained form Dakopatts, Copenhagen (the titer was $1600 \mathrm{mg} / \mathrm{l}$ as measured according to Becker (3)).

$20 \mu \mathrm{l}$ Serum was diluted with 3.5 and $7.0 \mathrm{ml}$ tris $0.002 \mathrm{~mol} / \mathrm{l}$ respectively. $100 \mu$ l of the serum dilutions were each added to $250 \mu \mathrm{l}$ anti-haptoglobin diluted 1:6 with tris $0.002 \mathrm{~mol} / \mathrm{l}$ and allowed to incubate at room temperature during 15 minutes. The turbidity was measured at $365 \mathrm{~nm}$ against serum and reagent blanks.

The hemoglobin binding capacity of the reference serum was determined by agar-electrophoresis according to van Ros \& van Sande (4).

Haptoglobin type determination was done by polyacrylamide disc-electrophoresis according to Dietz et al. (5).

\section{Results}

A series of dilution of a Haptoglobin type 2-1 serum, ranging from 0 to $270 \mu \mathrm{mol} / 1$ hemoglobin binding capacity was used as reference for determination of the haptoglobin content of the samples (fig. 1). A series of dilutions of a normal serum incubated with anti-haptoglobin- $0.002 \mathrm{~mol} / 1$ tris dilutions of respective fractions of $0.17,0.09$ and 0.05 of the original anti-haptoglobin titer demonstrate the normal optimum in absorbance (fig. 2). 


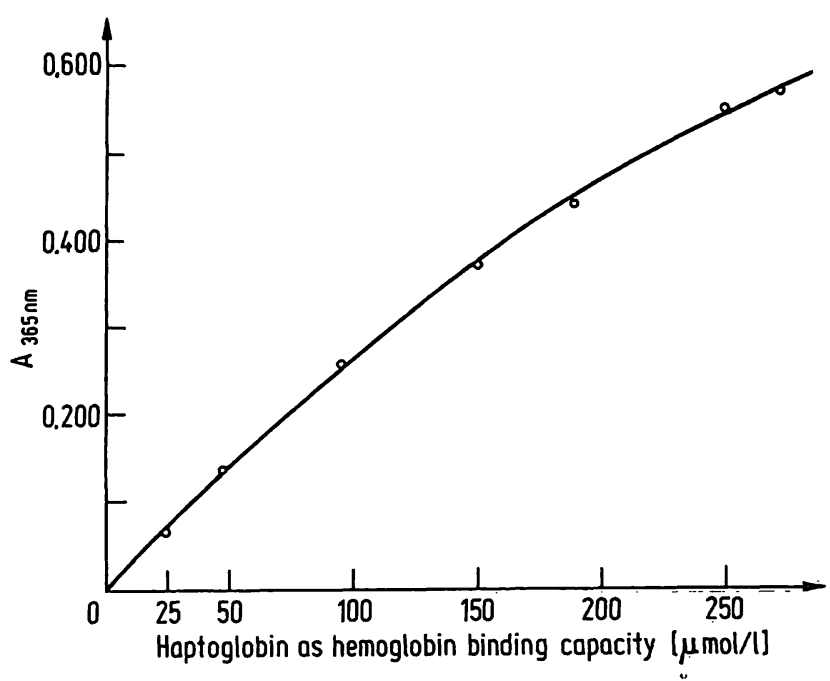

Fig. 1. Calibration-curve for the turbidimetric determination of haptoglobin, made from a dilution series of a haptoglobin-phenotype 2-1 serum containing $267 \mu \mathrm{mol} / 1$ hemoglobin binding capacity.

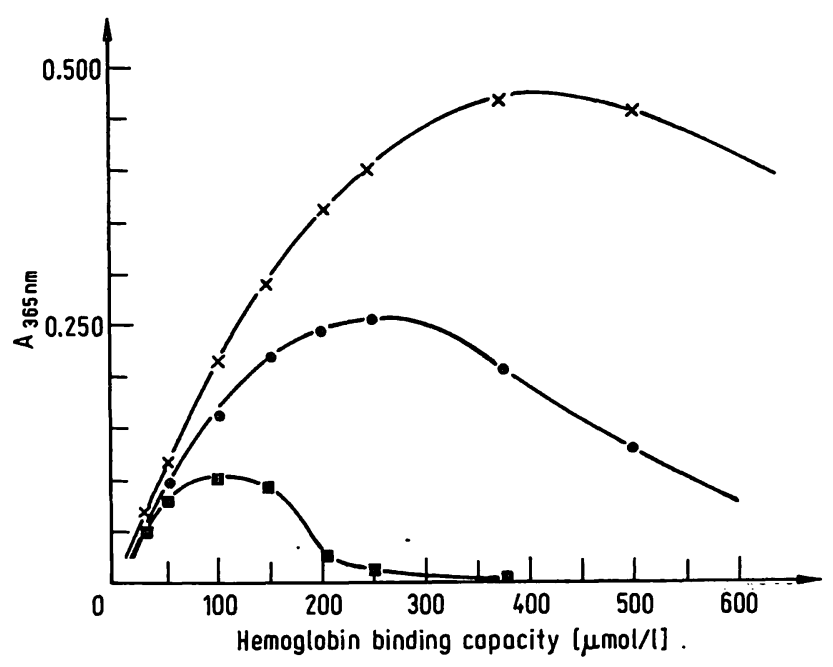

Fig. 2. Precipitin curves of a dilution series of a haptoglobin phenotype 2-1 serum incubated with anti-haptoglobin $0.002 \mathrm{mmol} / 1$ tris diluations of fractions $0.17(x-x)$, $0.09(\bullet-\bullet)$ and $0.05(--)$ of the original anti-haptoglobin titer which equals $1600 \mathrm{mg} / \mathrm{l}$.

An essentially different picture of the aggregates formed in the precipitin reaction is seen when the antigen concentration is kept constant and the anti-haptoglobin titer is varied. In figure 3 the turbidity for each of the three types of haptoglobin which were incubated with antiserum of increasing anti-haptoglobin titer is shown. A maximum absorbance of the haptoglobin-anti-haptoglobin aggregates is reached, which remains constant when the antihaptoglobin titer is increased.

The final turbidity is the same, whether the antiserum is added at once and incubated for 15 minutes, or e.g. in four parts, each part followed by 15 minutes incubation.

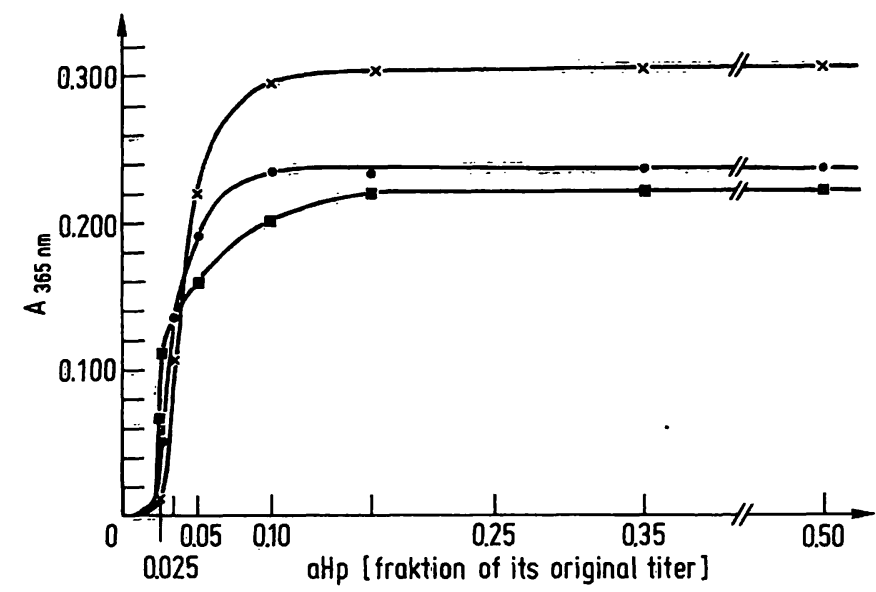

Fig. 3. Three different haptoglobin phenotypes incubated with anti-haptoglobin of increasing titer. (anti-haptoglobin fraction of 1.0 corresponds to a titer of $1600 \mathrm{mg} / \mathrm{l})$. $x$ type $1-1(120 \mu \mathrm{mol} / 1$ hemoglobin binding capacity) o type $2-1$ ( $95 \mu \mathrm{mol} / 1$ hemoglobin binding capacity) - type 2-2 (86 $\mu \mathrm{mol} / \mathrm{l}$ hemoglobin binding capacity)

To study the influence of hemoglobin, hemolysate $(15.4 \mu \mathrm{mol} / 1 \mathrm{Hb})$ prepared by the method of Lehmann \& Huntsman (6), was added to serum, and haptoglobin was determined according to the described method.

Haptoglobin concentrations determined turbidimetrically for dilutions with hemolysate, were the same as expected, when the dilution was made with $0.15 \mathrm{~mol} / \mathrm{l}$ saline:

$\begin{array}{ll}\text { Sample } & \begin{array}{l}\text { hemoglobin } \\ \text { binding capacity } \\ {[\mu \mathrm{mol} / 1]}\end{array} \\ & 125 \\ \text { serum-(undiluted) } \ldots & 125 \\ \text { serum-hemolysate } 1: 2 & 125 \\ \text { serum-hemolysate } 1: 3 & 124 \\ \text { serum-hemolysate } 1: 4 & 124\end{array}$

Obviously hemolysis which would occur after drawing of the blood samples did not influence the immunochemical determination of haptoglobin.

From 65 samples of normal and pathological serums (12 types 1-1, 38 types 2-1 and 15 types 2-2) haptoglobin was determined by agar-electrophoresis and by the turbidimetric method. For the agar-electrophoresis an excess of hemoglobin $(\mathrm{Hb})$ is added to the serum to be tested. The electrophoretic velocities of the $\mathrm{Hb}$ and hemoglobin-haptoglobin complexes are different. When a known quantity of $\mathrm{Hb}$ is added, the $\mathrm{Hb}$ binding capacity can be determined densitometrically at $400 \mathrm{~nm}$ from the ratio of both fractions.

Figure 4 shows the correlation between the electrophoretic and the turbidimetric method for each type. 


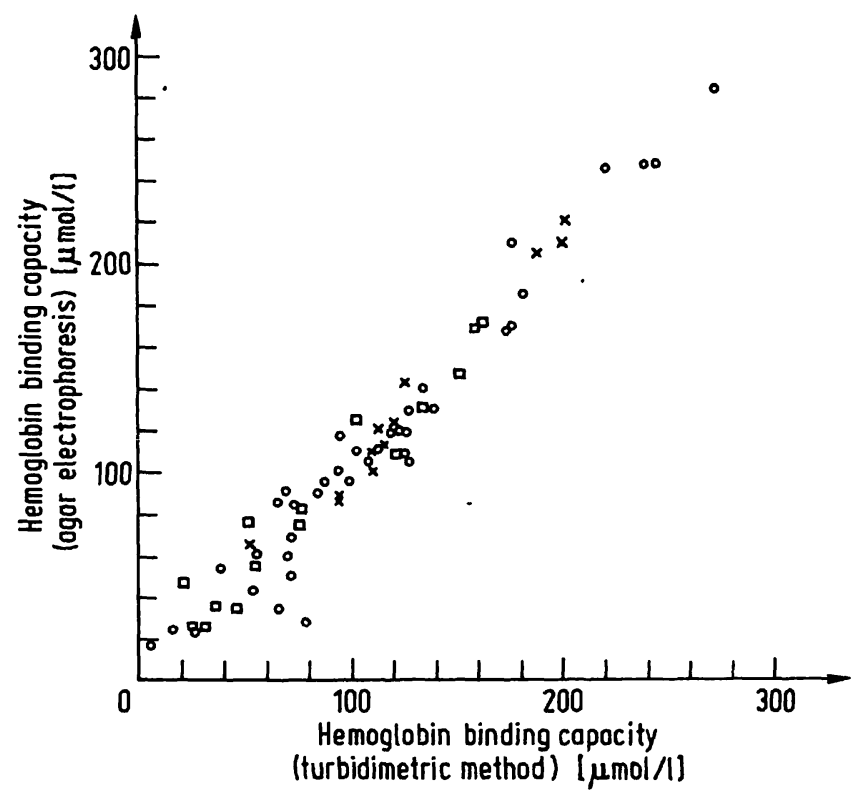

Fig. 4. Comparison of the agar-electrophoretic and turbidimetric method for determination of haptoglobin concentration. The middle regression lines are:

$x$ type 1-1: $y=1.08 x-6.3$ from $y=1.068 x-4,7$, $x=0.919 y+6.9, r=0.991$

$\circ$ type 2-1: $y=1.02 x+2.0$ from $y=0.990 x+4.9$, $x=0.959 y+1.0, r=0.974$.

$\square$ type 2-2: $y=1.02 x-1.3$ from $y=0.981 x+1.0$ $x=0.942 y+3.4, r=0.928$.

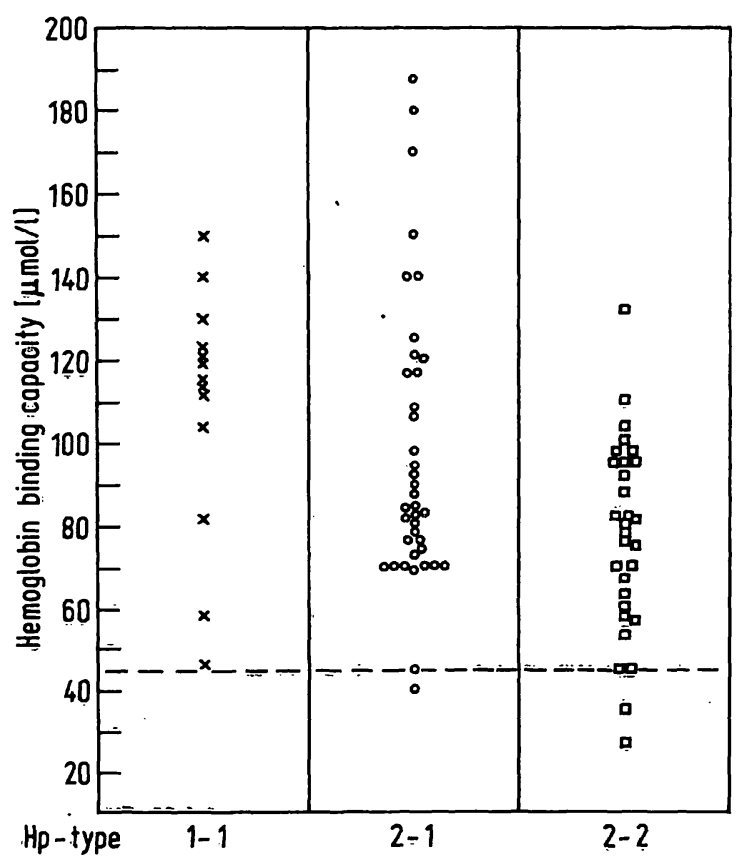

Fig. 5. Frequency diagram of the hemoglobin binding capacity of a group of 82 healthy blood donors, divided over the three haptoglobin phenotypes.

In a frequency diagram (fig. 5) hemoglobin binding capacity for a group of 82 healthy blood donors is shown for each type. The distribution of the haptoglobin phenotypes was as follows: type $1-116 \%$, type $2-146 \%$, type $2-238 \%$. Reference values computed from our data are: type 1-1 47-167, type $2-1$ 46-169 and type 2-2 28-124 $\mu \mathrm{mol} / \mathrm{l}$ hemoglobin binding capacity.

The described method has a variation coefficient of $2.7 \%$, and a day to day variation coefficient of $4.2 \%$.

\section{Discussion}

Immunochemical determinations of haptoglobin must be carried out with a $20 \mu \mathrm{l}$ serum sample, together with a diluted serum sample, thus ensuring that antiserum remains in excess.

At specific haptoglobin/antihaptoglobin ratios, aggregates of the antigen-antibody complex are formed which will precipitate. It may be assumed that the bindingsites of the antibody become occupied when additional serum-haptoglobin is added until finally an excess of haptoglobin does no longer results in the formation of precipitating aggregates of the complexes (fig. 2). An increased final antihaptoglobin concentration results in a higher absorbance of the formed aggregates, until a maximum absorbance is reached, which is not influenced by further increases in the antihaptoglobin concentration (fig. 3). In immuno-chemical reactions, when antibody is in excess, resolubilisation generally occurs when rabbit-antisera are used.

From a practical point of view it may be preferable to express haptoglobin concentration directly in physiologically relevant hemoglobin binding capacity. For all three phenotypes the described haptoglobin determination shows an analogous relation between the measured (turbidimetrically) hemoglobin binding capacity and the electrophoretic method (fig. 4). Different reference values were found for the three haptoglobin phenotypes 1-1, 2-1 and 2-2 represented in the group of donors (fig. 5).

It seems that for the types 1-1 and 2-2 a normal distribution exists, whereas for type 2-1 the distribution is lognormal. No explanation was found for the different types of distribution.

As the three haptoglobin-phenotypes show a similar correlation between the immunochemical method and the direct measurement of hemoglobin binding capacity, other haptoglobin phenotype sera may be used for standardisation.

The lower limits of the normal range were:

type $1-1,47 \mu \mathrm{mol} / 1$ hemoglobin binding capacity; type 2-1, $46 \mu \mathrm{mol} / 1$ hemoglobin binding capacity, type $2-2,25 \mu \mathrm{mol} / 1$ hemoglobin binding capacity. With the selection of $45 \mu \mathrm{mol} / 1$ hemoglobin binding capacity as the common lower limit for all types, $2 \%$ of the normal values would incorrectly fall below this limit. 
Likewise it is possible to assume $170 \mu \mathrm{mol} / \mathrm{l}$ hemoglobin binding capacity as the upper limit, which means that raised values of haptoglobin types 2-2 ranging from $125-175 \mu \mathrm{mol} / \mathrm{l}$ hemoglobin binding capacity are falsely interpreted as normal. For accurate interpretation in this range haptoglobin-typing is necessary.

Mean serum-haptoglobin concentrations and standard deviations for other haptoglobin determinations are given by Braun \& Aly (7).

\section{References}

1. Schultze, H. E. \& Schwick, G. (1959), Clin. Chim. Acta 4, 15-25.

2. Kreutzer, H. J. (1976), this j. 14, 401-406.

3. Becker, W. (1969), Immunochemistry 6, 539-546.

4. van Ros, G. \& van Sande, M. (1964), Clin. Chim. Acta 10, 62-72.
Our results are in good agreement with most of the reported values.

\section{Acknowledgement}

We are grateful to Miss Ans Antonie for her skillful technical assistance.
5. Dietz, A. A., Lubrano, T. \& Rubinstein, H. M. (1971), Clin. Biochem. 4, 59-67.

6. Lehmann, H. \& Huntsman, R. G. (1966), Man's haemoglobins. Lippincott, Philadelphia, pp. 268.

7. Braun, H. J. \& Aly, F. W. (1971), this j. 6, 508-515.

J. M. Ramakers and H. J. H. Kreutzer Croot Ziekengasthuis

Klinisch Chemisch Lab.

Nieuwstraat 34

Den Bosch

Nètherlands 